\title{
STORAGE AND QUALITY OF APPLES 'REINETTE SIMIRENKO', DEPENDING ON THE DOSE OF POST-HARVEST TREATMENT WITH ETHYLENE INHIBITOR 1-MCP
}

\author{
Oleksandr MELNYK, Olha DROZD*, Ihor MELNYK \\ Uman National University of Horticulture \\ Ukraine
}

Received: November 2018; Accepted: March 2019

\begin{abstract}
Natural weight losses, flesh and core browning, senescent breakdown and fruit rot, ethylene-production, firmness, soluble solids content, titratable acidity and taste of apple 'Reinette Simirenko' during storage, depending on the dose of postharvest treatment with 1-methylcyclopropene (1-MCP) were studied. Fruits were collected in harvesting maturity and treated with 1-MCP at the recommended dose of $1000 \mathrm{ppb}$ $\left(\right.$ SmartFresh $\left.^{\mathrm{TM}} 0.068 \mathrm{~g} \cdot \mathrm{m}^{-3}\right)$ and experimental doses of $750 \mathrm{ppb}(75 \%$ of the recommended dose) and $500 \mathrm{ppb}(50 \%)$. Apples were stored at $2 \pm 1{ }^{\circ} \mathrm{C}$ and air humidity $85-90 \%$. After seven months of cold storage, irrespective of dose of 1-MCP, on the 20th day of shelf-life, ethylene production from the treated apples was 3.9-5.3 times lower than that of the untreated ones. During the seven months of storage, fruits with post-harvest treatment had high firmness - 8.8-9.0 kg without a significant difference in range of 500$1000 \mathrm{ppb} 1-\mathrm{MCP}$. 1-MCP treatment provides $0.6-1.0 \%$ higher content of soluble solids (highest level is for the treatment of 750 and $1000 \mathrm{ppb}$ ). Content of titratable acidity was higher by 1.4-1.7 times (the highest acidity was at $1000 \mathrm{ppb}$ and, respectively, 1.1 and 1.2 times lower when treated with doses of 750 and $500 \mathrm{ppb}$ ). There was no skin browning and senescent breakdown and no flesh browning at 750 and $1000 \mathrm{ppb}$, and no fruit rot at $1000 \mathrm{ppb}$. When smaller doses (as recommended) are applied, a more harmonious taste of apples without reducing storage ability is achieved.
\end{abstract}

Keywords: apples, 1-MCP, diseases, ethylene, physical-chemical parameters, taste

\section{INTRODUCTION}

The ripening hormone, ethylene plays a leading role in metabolism and activates even in small quantities the metabolism of the fruits. In 1990s, the US researchers found that post-harvest treatment with 1-methylcyclopropene (1-MCP) blocked the effect of ethylene on the ripening of apples (Sisler $\&$ Blankenship 1996). Since 2002, 1-MCP has been included as an active substance of the drug SmartFresh (Blankenship 2001), which has been widely used in Ukraine since 2009.

Post-harvest treatment of fruits with 1-methylcyclopropene minimizes the negative influence of stress storage conditions, in particular, the untimely installation and fluctuation of temperature and gas composition of the atmosphere. As a result of ethylene blocking, the risk of apple damage by superficial browning of the skin (scald), low temperature disorders and fungal diseases is reduced (Jeziorek et al. 2010).

Fruits of the so-called hard cultivars should come to the market with a flesh firmness of at least $5.5 \mathrm{~kg}$ (Tomala et al. 2010). In the conditions of increased temperature, after shipment from the refrigerator firmness is lost faster, therefore, immediately after storage its level should be $1.0 \mathrm{~kg}$ higher.

The effect of post-harvest treatment depends on the pomological variety, storage conditions (Watkins et al. 2000), and dose of 1-MCP, with the increase of which the effect of treatment also increases (Ekinci et al. 2016). For the post-harvest 
treatment of apples, a dose of $0.068 \mathrm{~g} \cdot \mathrm{m}^{-3}$ of SmartFresh VP 3.3\% (1000 ppb) was registered in Ukraine; while in Poland, it was $0.037-0.049 \mathrm{~g} \cdot \mathrm{m}^{-3}$ (Etykieta SmartFresh 2016), in France - 0.043 (Anses SmartFresh 2014), in Italy - 0.043-0.068 (Etichetta SmartFresh 2016), in Germany - 0.049 (SmartFresh VP 2016) and it was $0.051-0.067 \mathrm{~g} \cdot \mathrm{m}^{-3}$ in the United States (US EPA 2010). However, extremely high doses of 1-MCP can cause the loss of the characteristic pomological flavor of the apples, an important indicator of fruit quality (Beaudry \& Watkins 2003; Vidrih et al. 2011).

Fruits of one of the leading late-winter apple cultivars in Ukraine - Reinette Simirenko - are significantly affected by physiological disorders, in particular skin and flesh browning and senescent breakdown (overripening), which limits the economically reasonable longevity of a common cold storage up to 5-6 months. Post-harvest SmartFresh treatment increases the storage life of fruits of this cultivar up to seven months, significantly reducing the damage by rotting, skin and flesh browning, and rare signs of senescent breakdown (Melnyk et al. 2017). However, due to the preservation of high levels of titratable acidity, the taste of the fruits is too sour, which does not contribute to the market reputation of this valuable cultivar (Melnyk \& Drozd 2012a). In addition, due to the threat of damage by early autumn frost in the first decade of October and the undesirable dirty brown coloring of the skin that worsens the appearance of fruits, apples of cv. 'Reinette Simirenko' in the middle climate zone of Ukraine are often harvested prematurely.

The aim of this study was to improve the taste of 'Reinette Simirenko' apples by post-harvest treatment with a different dose of 1-methylcyclopropene (SmartFresh ${ }^{\mathrm{TM}}$ ), as well as to identify the level and natural weight losses, changes of ethylene activity, physical and chemical parameters and tasting evaluation during conventional cold storage.

\section{MATERIALS AND METHODS}

The research was conducted in the storage season 2013/2014 at the Department of fruit growing and viticulture of Uman National University of Horticulture. Apples of cv. 'Reinette Simirenko' were collected in Khotyn district, Chernivtsi region, Ukraine and stored in the experimental cool room at the Department of fruit growing and viticulture. Planning, conducting the experiment and processing of the results were performed by standard methods.

The apples were harvested in the stage of harvest maturity in the full fruiting irrigated orchard on dwarf rootstock M.9 with a planting scheme $3.5 \times$ $1.0 \mathrm{~m}$, with grass in the interrows and herbicide strips under trees. Fruits of uniform maturity were selected with a diameter of 75-90 mm. Immediately, accounting units were formed, apples were inspected for the absence of damage and put into paper-lined $22 \mathrm{~kg}$ boxes. Also, polyethylene nets with fruits were put there to record natural weight losses. The number of boxes of each option corresponded to the periodicity of the analysis.

On the day of collection, the products were cooled at $5 \pm 1^{\circ} \mathrm{C}$ and relative air humidity of 85 $90 \%$, avoiding the presence of an external source of ethylene - fruits not intended for research. The following day, the apples were 1-MCP treated with a recommended dose of $1000 \mathrm{ppb}$ and experimental doses $750 \mathrm{ppb}$ (75\% of the recommended amount) and $500 \mathrm{ppb}(50 \%)$; the untreated fruits were the control. For this purpose, the boxes with fruits were placed in a gas-tight container of a polyethylene film of 200 microns thick, where a glass of distilled water and a powdered preparation, calculated per volume unit, were placed. The circulation of air in a container was carried out by the battery powered (operated) fan.

After 24-hour exposure, the film container was removed, and the treated and control fruits in the boxes were stored at $2 \pm 1{ }^{\circ} \mathrm{C}$ and relative air humidity of $85-90 \%$. Untreated (control) and treated fruits were placed side by side. The temperature in the chamber was measured with alcohol thermometers, the air relative humidity - with a hygrometer.

At harvest, flesh firmness of apples, the content of soluble solids, titratable acidity, iodine/starch test (on the CTIFL scale) and Streif index were determined. The estimation of weight loss during storage was periodically done by weighing polyethylene nets with fruit before and after storage. The number of fruits affected by skin and flesh browning, senescent breakdown and rotting (affected 
by fungal diseases) was determined in comparison with the total number of fruits (in percentages). The analyses were performed monthly from the second to the seventh month of storage.

The intensity of fruit ethylene production $\left(\mu 1 \cdot \mathrm{kg}^{-1} \cdot \mathrm{hr}^{-1}\right)$ was periodically measured with gas analyzer ICA-56 (International Controlled Atmosphere Ltd) with an accuracy of $\pm 0.1 \mathrm{ppm}$ in the range of $0-100 \mathrm{ppm}$ after removing from the cold store and 24-hour warming of fruits, the first measurement was done at $18-20{ }^{\circ} \mathrm{C}$ and further ones were conducted during shelf-life at the same temperature and relative humidity of 55-60\%. Measurements were made on separate batches of fruits. A sample of three or four fruits of a weight approximately $0.5 \mathrm{~kg}$ was placed in a 4 liter airtight jar and maintained for $0.5-1.0 \mathrm{~h}$ at $18-20^{\circ} \mathrm{C}$ (Melnyk 2010).

In a 20-fruit sample, the flesh firmness was determined with penetrometer FT-327 with an 11-mm plunger mounted on a tripod, with two measurements on each apple (skin was removed before the measurement). The content of soluble solids (Brix \%) was determined with a hand refractometer RHB32 ATC and titratable acidity was determined by dissolving a known weight of sample in distilled water and titration against $0.01 \mathrm{~N} \mathrm{NaOH}$ using phenolphthalein as the indicator.

Apple organoleptic evaluation was carried out by a permanent panel of 10 people after six months of storage and a week shelf-life at $20{ }^{\circ} \mathrm{C}$ and relative humidity of 55-60\%. Samples of three apples were blind, marked with numbers. Aroma, hardness, crispiness, juicy, mealiness, sweet taste, sour taste and overall assessment were assessed as 10 points perfectly and 1 point - unsatisfactory. Sweet/sour index as the ratio of sweet taste to the sour taste were determined. The effect of the studied factors was evaluated with a multivariate analysis of variance by Statistica 6 with LSD at $\mathrm{p}<0.05$.

\section{RESULTS AND DISCUSSION}

During the harvesting, flesh firmness of apples was $10.4 \mathrm{~kg}$, the content of dry soluble solids was $12.1 \%$, titratable acidity $-0.80 \%$, iodine/starch test 2 points (on the CTIFL scale) and 0.43 - Streif index.
Regardless of the dose of 1-MCP for post-harvest treatment, during the six-month storage time, the losses caused by physiological disorders and fungal diseases were not found. After seven months of storage, the decline in the output of commodity products is mainly due to the browning of the skin (superficial scald) and flesh browning, senescent breakdown and fruit rot. On average, in the experiment, the losses of untreated fruits after sevenmonth storage due to skin browning and senescent breakdown were found to be $29.5 \%$ and $44.4 \%$, respectively, and for post-harvest treatment those were absent, regardless of the dose of 1-MCP. The damage absence of scald-sensitive apples cv. 'Granny Smith', treated with 1-MCP, was established by Moggia et al. (2009).

After a seven-month storage period, also no flesh browning of apples with a post-harvest treatment with doses of 750 and $1000 \mathrm{ppb}$ was found, while for untreated fruits and treated with a dose of $500 \mathrm{ppb}$, the losses caused by this disorders were 10 and $9 \%$, respectively (Fig. 1).

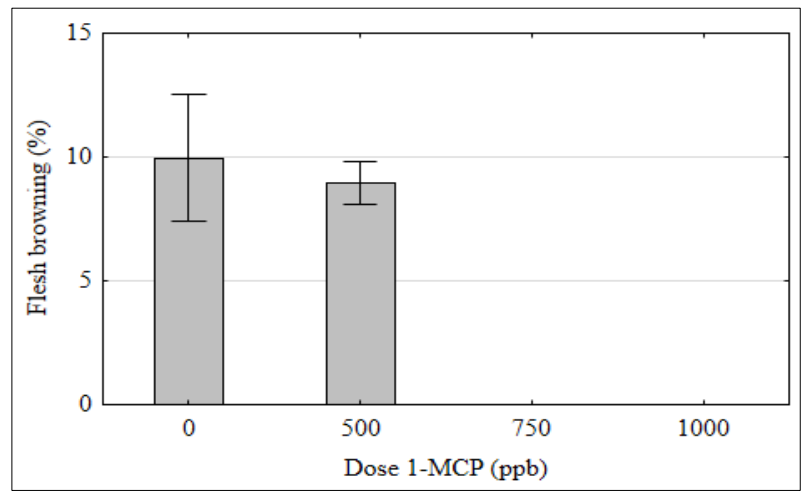

Fig. 1. Damage of apples 'Reinette Simirenko' by the flesh browning after post-harvest treatment with different doses of 1-MCP and seven months of storage

There was no fruit rot for apples treated with a dose of $1000 \mathrm{ppb}$. A significant difference between the level of decay of untreated apples and the treated ones with doses of 500 and $750 \mathrm{ppb}$ was not found out, however, at a higher dose of 1-MCP, the losses from the fruit rot were lower (Fig. 2). Similar results were obtained by Melnyk et al. (2017) for apples 'Reinette Simirenko' and Ekinci et al. (2016) for 'Granny Smith' cultivar. 
Natural weight losses. Natural weight losses of fruit during storage were steadily increasing (Fig. 3). After two months of storage, the rate of untreated fruits and the treated ones with doses of 750 and $1000 \mathrm{ppb}$ reached a level of $1.5-1.6 \%$ and 1.3 times higher after treatment with a dose of $500 \mathrm{ppb}$. Starting from the third month, after a treatment with a dose of $1000 \mathrm{ppb}$ (750 dose from the fifth), the weight loss slowed down significantly, compared with the untreated fruits. After seven months, the weight loss of untreated fruits and apples treated with $500 \mathrm{ppb}$ reached a level of 5.3\%. At the same time, the lowest level $4.3 \%$ was achieved after postharvest treatment with a dose of $750 \mathrm{ppb}$ and $5.0 \%$ at $1000 \mathrm{ppb}\left(\mathrm{LSD}_{0.05}=0.2\right)$. Similar results of the positive effect of the post-harvest treatment with ethylene inhibitor on weight loss of 'Granny Smith' apples were received by Akbudak et al. (2009).

Ethylene activity. Post-harvest treatment with 1methylcyclopropene significantly inhibited an ethylene production rate of recently harvested fruits (Fig. 4). Ethylene production of untreated fruits steadily increased, and it reached a level of $16.9 \mu 1 \cdot \mathrm{kg}^{-1} \cdot \mathrm{hr}^{-1}$ on the $40^{\text {th }}$ day of shelf-life. Regardless of the 1-MCP dose, during first 30 days, the rate of ethylene production of treated fruit ranged within $0.21-0.41 \mu 1 \cdot \mathrm{kg}^{-1} \cdot \mathrm{hr}^{-1}$ and it increased to a level of 3.4-5.6 $\mu \mathrm{l} \cdot \mathrm{kg}^{-1} \cdot \mathrm{hr}^{-1}$ on the 40th day of shelf life, which was less than the value of untreated apples by 3-5 times. No correlation between the dose of 1-MCP and ethylene production was found. A similar trend was also observed after seven months of cold storage (Fig. 5). Untreated fruits generated 27.1-64.1 times more ethylene than the treated ones, and the intensity of the process increased during the first 10 days of shelf-life at $20^{\circ} \mathrm{C}$ (with a further slight decrease). Similar results for 1-MCP treated apples 'Granny Smith' with doses 625 and $1250 \mathrm{ppb}$ during storage were obtained by Ekinci et al. (2016).

Ethylene production of treated apples slightly increased after five days of shelf-life with a subsequent index increase independent of the 1-MCP dose. On the $20^{\text {th }}$ day of the shelf life, ethyleneemission of the treated fruit reached a level of 5.2$7.1 \mu \mathrm{l} \cdot \mathrm{kg}^{-1} \cdot \mathrm{hr}^{-1}$, which was 3.9-5.3 times lower than that of the untreated ones.

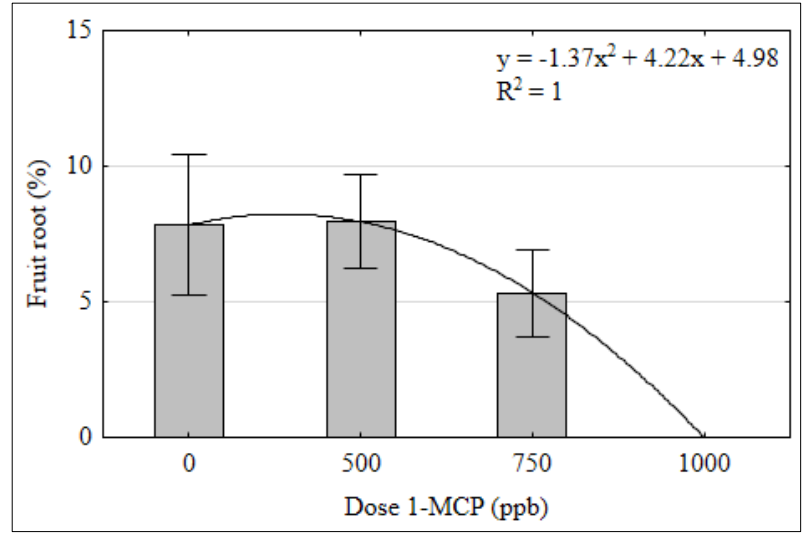

Fig. 2. Damage of apples cv. 'Reinette Simirenko' by the fruit rot after post-harvest treatment with different doses of 1-MCP and seven months of storage

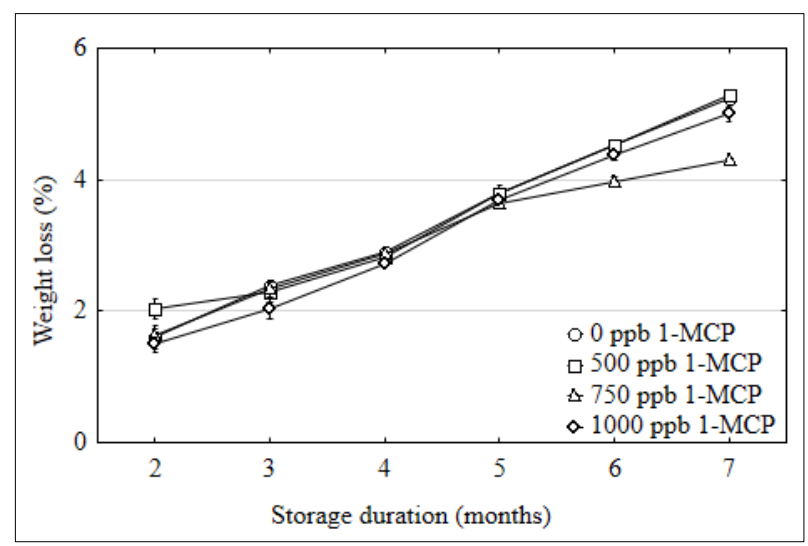

Fig. 3. Change of natural weight losses of apple cv. 'Reinette Simirenko', treated with different doses of 1-MCP, during storage (the indicator of untreated fruit is similar to that of the treated ones with dose of $500 \mathrm{ppb}$ )

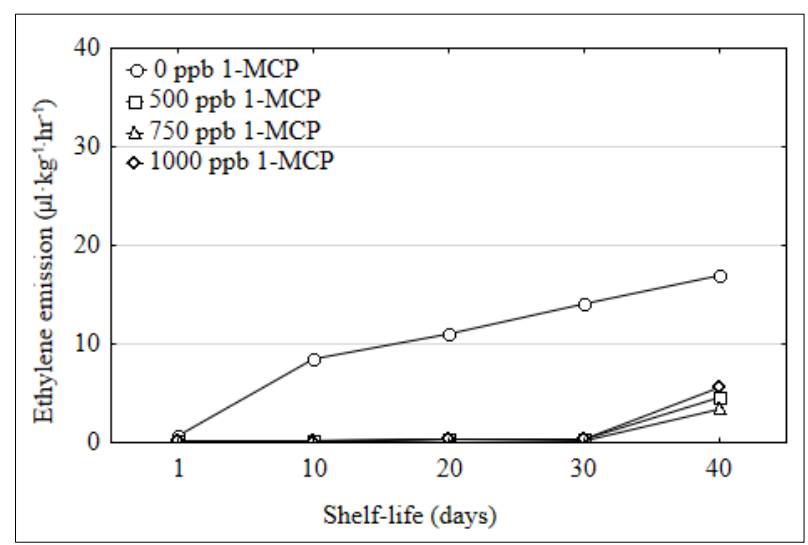

Fig. 4. Ethylene production at a temperature of $20^{\circ} \mathrm{C}$ by freshly harvested apples cv. 'Reinette Simirenko', depending on the dose of post-harvest treatment 1-MCP 


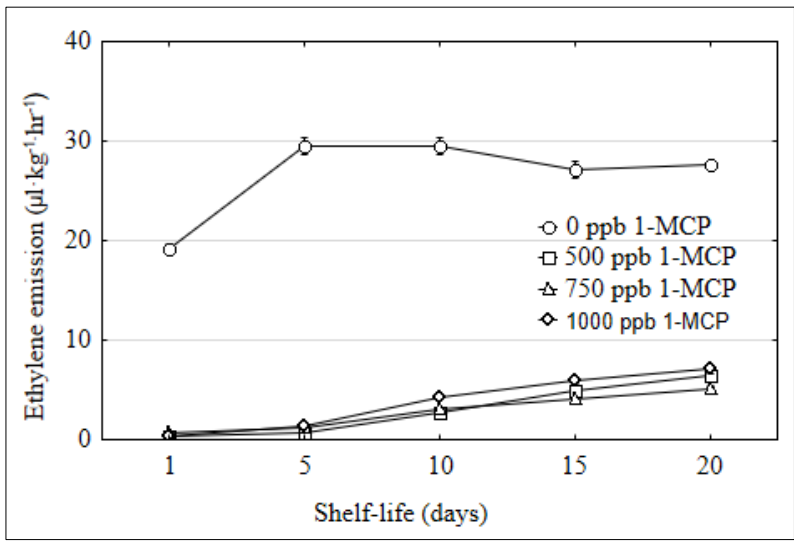

Fig. 5. Ethylene production at a temperature of $20^{\circ} \mathrm{C}$ apples cv. 'Reinette Simirenko' after seven months of storage, depending on the dose of post-harvest treatment 1-MCP

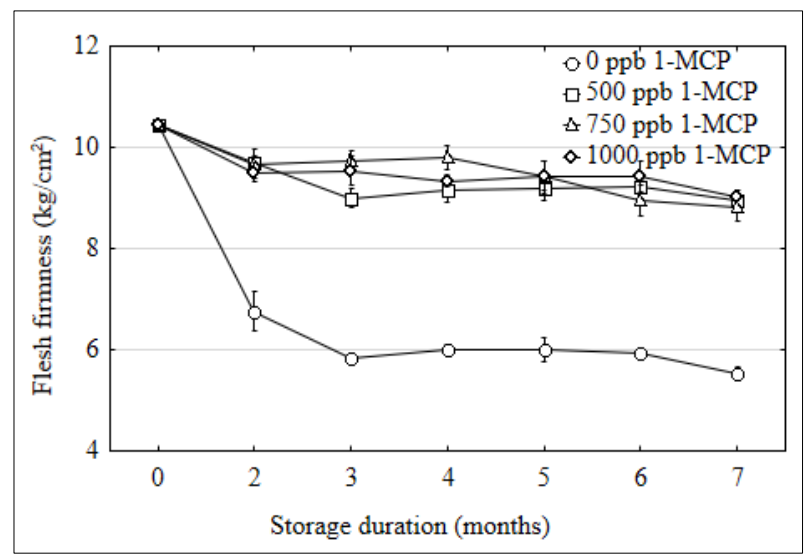

Fig. 6. Change in the flesh firmness of apples cv. 'Reinette Simirenko', treated with different doses of 1-MCP, during cold storage

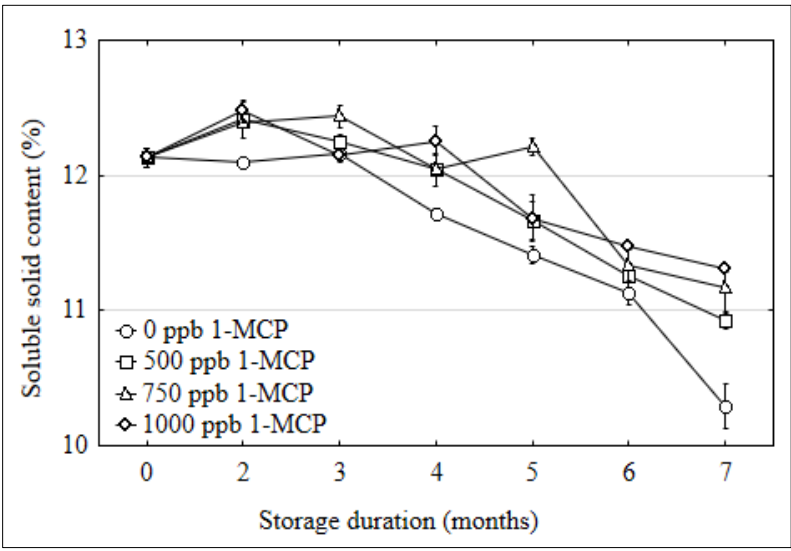

Fig. 7. Change in the content of soluble solids in apples cv. 'Reinette Simirenko', treated with different doses of 1-MCP, during cold storage
Flesh firmness. Flesh firmness of non-treated fruits was actively reduced, especially in the initial period of cold storage (Fig. 6). Taking into account that for shipment to the trading network, it is necessary that the firmness of apples is kept not less than $6.5 \mathrm{~kg}$, for untreated fruits it was possible only during the first two months of storage. Therefore, without postharvest treatment with an ethylene inhibitor, apples of 'Reinette Simirenko' are suitable for sale only during the first two months of storage at $2 \pm 1{ }^{\circ} \mathrm{C}$. Similar results at temperature $1{ }^{\circ} \mathrm{C}$ were obtained by Bai et al. (2005) for 'Granny Smith' apples and by Melnyk and Drozd (2012b) at $3{ }^{\circ} \mathrm{C}$ for cv. 'Reinette Simirenko'.

Post-harvest 1-MCP treatment provided a high level of flesh firmness $-8.8-9.0 \mathrm{~kg}$ at the end of sevenmonth storage without a significant difference between the doses of 1-MCP used.

Soluble solids content and titratable acidity. In the initial period of storage, the content of fruit dry soluble substances increased to a certain extent, further substantially decreasing (Fig. 7). The level of total soluble solids in the untreated fruits decreased more intensively, reaching a value of $10.3 \%$ at the end of the seven-month storage. Regardless of the 1-MCP dose, after a two-month storage time, the index level for apples with post-harvest treatment with an ethylene inhibitor was $0.3-0.4 \%$ higher, compared with the untreated fruits (only for a dose of $750 \mathrm{ppb}$ after three months). After four months, the fruits treated with all doses of 1-MCP had the highest content of total soluble solids, after five months the highest content $(12.2 \%)$ was found at $750 \mathrm{ppb}$, and after six months - at $1000 \mathrm{ppb}(11.5 \%)$.

Thus, the post-harvest 1-MCP treatment provided significantly higher content of total soluble solids at the end of the seven-month storage of apples 'Reinette Simirenko' with the highest level for a dose of $1000 \mathrm{ppb}$. Similar results for this cultivar, when treated with a dose of $1000 \mathrm{ppb}$, were previously obtained by Drozd et al. (2018).

The content of titratable acidity steadily decreased during storage (Fig. 8). Within the first four months, no significant impact of post-harvest treatment with an ethylene inhibitor on the change of titratable acidity was recorded, and after five months, a significantly higher acidity level for all the studied 
doses of 1-MCP (compared to untreated fruits) was observed. After six months of storage, a higher titratable acidity by $0.14-0.15 \%$ was found in postharvest treated fruits regardless of the dose of 1$\mathrm{MCP}$, and at the end of the seven-month storage period, the highest level was achieved at doses of 750 and $1000 \mathrm{ppb}$. At the same time, the titratable acidity of the untreated apples was lower by 1.4-1.7 times. A similar dependence was obtained by Magazin et al. (2017) for cv. 'Granny Smith', stored in CA with 1-MCP treatment at 500, 1000 and $2000 \mathrm{ppb}$.

Tasting score. Regardless of the dose of 1-MCP, the apples with post-harvest treatment with an ethylene inhibitor demonstrated a significantly slower process of ripening and forming the aroma, however, at the end of six month storage, the hardness index was twice as much higher, compared with the untreated fruits (Table 1).

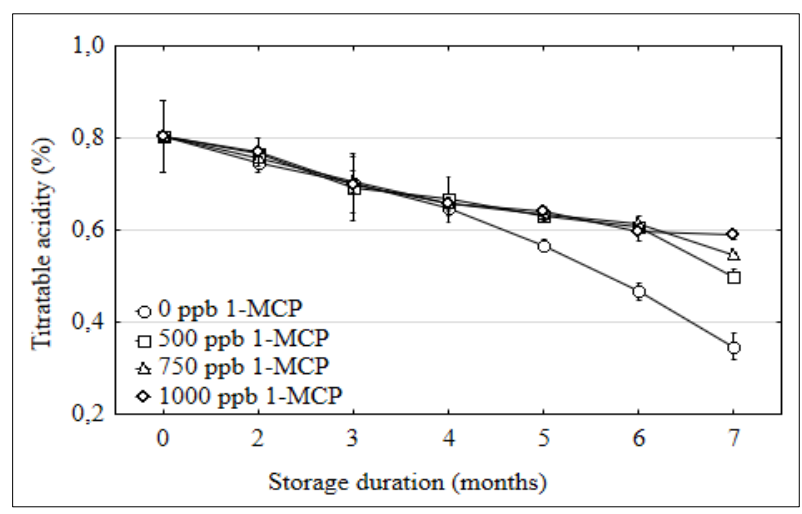

Fig. 8. Change in the content of titratable acidity in apples of cv. 'Reinette Simirenko', treated with different doses of 1-MCP, during cold storage

Table 1. Organoleptic evaluation of apples 'Reinette Simirenko' with post-harvest treatment at different doses of 1MCP after six months of storage and a week-shelf life at $20{ }^{\circ} \mathrm{C}$ (crop 2013)

\begin{tabular}{|c|c|c|c|c|c|c|c|c|c|}
\hline $\begin{array}{c}\text { Dose of SmartFresh } \\
(\mathrm{ppb})\end{array}$ & Aroma & Hardness & Crispness & Juiciness & Mealiness & $\begin{array}{l}\text { Sweet } \\
\text { taste }\end{array}$ & $\begin{array}{l}\text { Sour } \\
\text { taste }\end{array}$ & $\begin{array}{c}\text { Sweet/sour } \\
\text { index }\end{array}$ & $\begin{array}{c}\text { Overall } \\
\text { score }\end{array}$ \\
\hline 0 (Control) & 6,7 & 3,1 & 3,5 & 3,7 & 7,8 & 5,7 & 3,7 & 1,5 & 5,1 \\
\hline 500 & 4,2 & 7,5 & 7,5 & 7,9 & 2,3 & 4,8 & 6,3 & 0,8 & 7,1 \\
\hline 750 & 3,8 & 7,3 & 7,2 & 7,8 & 2,2 & 5,2 & 7,2 & 0,7 & 6,8 \\
\hline 1000 & 4,2 & 7,2 & 7,6 & 7,9 & 2,7 & 3,8 & 7,8 & 0,5 & 7,2 \\
\hline $\mathrm{LSD}_{0.05}$ & 1,4 & 1,1 & 1,2 & 1,2 & 1,2 & 1,4 & 1,4 & 0,2 & 1,6 \\
\hline
\end{tabular}

Compared with the untreated fruits at postharvest treatment with the ethylene inhibitor, there was no mealiness, hardness was 2.4 times higher, crispness and juiciness -2.1 times higher, but the aroma of the treated fruit was 2.5-2.9 points lower, regardless of 1-MCP dose. The evaluation of sweetness of the fruits with post-harvest treatment at doses of 500 and 750 ppb (4.8-5.7, a 10-point scale) was almost similar to the untreated apples, but at $1000 \mathrm{ppb}$ this indicator of the treated fruit was lower by $1.3-1.5$ times. The degree of sour taste of the fruits treated with a dose of $1000 \mathrm{ppb}$ was twice higher than that of the untreated ones; it was 1.9 times higher in the apples with a treatment of $750 \mathrm{ppb}$ and 1.7 times higher at $500 \mathrm{ppb}$. The least sour fruits were those treated with ethylene inhibitor at a dose of $500 \mathrm{ppb}$. The sweet/sour index of the untreated fruits was 1.9-2.1 times higher as compared with the 1-MCP treated apples with doses of 500 and $750 \mathrm{ppb}$ and
3.0 times higher than the ones treated at $1000 \mathrm{ppb}$ dose. Due to hardness, crispiness, juiciness and lack of mealiness, the treated fruits received 1.3-1.4 times higher total score than the untreated ones (regardless of the 1-MCP dose).

\section{CONCLUSIONS}

1. The post-harvest ethylene production of the latewinter apples cv. 'Reinette Simirenko', without ethylene inhibitor treatment, increases steadily at $20{ }^{\circ} \mathrm{C}$, whereas it is not recorded in the postharvest 1 -MCP treated fruits for almost 30 days, regardless of the dose, and after 40 days of exposure, it is lower by 3-5 times compared with the untreated fruits. After seven months of common cold storage, untreated fruits produced 27.164.1 times more ethylene than those treated with 1-MCP, and during 10-day shelf-life at $20^{\circ} \mathrm{C}$, 
the intensity of the process increases with a further minor decrease. Regardless of the 1-MCP dose, ethylene production rate of treated apples is slightly activated after the first five days of exposure, but on the $20^{\text {th }}$ day, their ethylene activity is 3.9-5.3 times lower than that of the untreated ones.

2. The sale-permissible flesh firmness of the untreated fruit at a level of $6.5 \mathrm{~kg}$ is provided when cv. 'Reinette Simirenko' apples are stored at $2 \pm 1{ }^{\circ} \mathrm{C}$ for not longer than two months. Postharvest treatment with an ethylene inhibitor provides high firmness - 8.8-9.0 kg during the sevenmonth storage without a significant difference in the range of 1-MCP doses 500-1000 ppb.

3. The content of total soluble content of post-harvest treated fruits with an ethylene inhibitor is higher by $0.6-1.0 \%$ after seven months of storage (as compared with the untreated ones) with the highest level after treatment with dose of 750 and $1000 \mathrm{ppb}$. After four-month storage, the fruits with post-harvest 1-MCP treatment have higher titratable acidity and it is higher by 1.41.7 times after seven months. The highest titratable acidity of the fruits is recorded after the treatment with a dose of $1000 \mathrm{ppb}$, and with doses 750 and $500 \mathrm{ppb}$, it is lower by 1.1 and 1.2, respectively.

4. After six months of storage, the 1-MCP treated fruits had no mealiness; they had a high level of hardness, crispiness, juiciness and overall tasting, and after treatment with 500 and $750 \mathrm{ppb}$ doses, the apples were sweeter. The sweet/sour index of the untreated fruits is 1.9-2.1 times higher, in comparison with the 1-MCP treated ones with doses of 500 and 750 , and it is 3.0 times higher, compared with the fruits treated with $1000 \mathrm{ppb}$.

5. Postharvest treatment 1-MCP with a dose of $1000 \mathrm{ppb}$ effectively reduces the natural weigh losses of apples from the third month of storage at $2 \pm{ }^{\circ} \mathrm{C}$, and from the fifth month fruit treated of $750 \mathrm{ppb}$. After seven months, the natural loss of untreated fruits, as well as treated $500 \mathrm{ppb}$, is 1.1-1.2 times higher than apples with a treatment of 750 and $1000 \mathrm{ppb}$, with the lowest level of losses in latter ones.
6. Late-winter apples of cv. 'Reinette Simirenko' treated with an ethylene inhibitor (1-MCP) after picking are stored for a period of six months or more at $2 \pm 1{ }^{\circ} \mathrm{C}$ with less than $10 \%$ loss. Regardless of the 1-MCP dose, after seven months of storage, there is no skin browning (scald) and senescent breakdown, the losses of the untreated fruits caused by them, are 29.5 and $44.4 \%$, respectively. After treatment with a dose of 750 and $1000 \mathrm{ppb}$, no browning of the flesh is recorded, and at $1000 \mathrm{ppb}$ dose there is no fruit rot.

7. A high efficiency of post-harvest treatment of cv. 'Reinette Simirenko' apples with an ethylene inhibitor is ensured in a wide range of 1-MCP doses - 500-1000 ppb. At lower doses, a more harmonious taste of apples is achieved without reducing storage ability.

\section{Acknowledgement}

The authors express their gratitude to "Janis" for providing apples, "AgroFresh" (Poland) for providing "SmartFresh $^{\mathrm{TM}}$ " preparation and ICA-56 device to carry out trials.

\section{REFERENCES}

Akbudak B., Ozer M.H., Erturk U., Cavusoglu S. 2009. Response of 1-methylcyclopropene treated 'Granny Smith' apple fruit to air and controlled atmosphere storage conditions. Journal of Food Quality 32(1): 18-33. DOI: 10.1111/j.1745-4557.2008.00233.x.

Anses - dossier № 2012-2972 - SMARTFRESH (AMM № 2050073). 2014: 1-8. http://agriculture.gouv.fr/sites/minagri/files/documents/pdf/AVIS_EXMA_SMARTFRESH_cle0229e7.pdf. [in French]

Bai J., Baldwin E.A., Goodner K.L., Mattheis J.P., Brecht J.K. 2005. Response of four apple cultivars to 1-methylcyclopropene treatment and controlled atmosphere storage. HortScience 40(5): 1534 1538. DOI: $10.21273 /$ hortsci.40.5.1534.

Beaudry R., Watkins C. 2003. Use of 1-MCP on apples. New York Fruit Quarterly 11(1): 11-13.

Blankenship S. 2001. Discovery and commercialization of 1-MCP as an ethylene inhibitor. Perishables Handling Quarterly 108: 5. https://ucanr.edu/sites/Postharvest_Technology_Center_/files/230797.pdf

Drozd O.O, Melnyk O.V., Melnyk I.O. 2018. Chemical composition of apples cv. Reinette Simirenko, 
treated with ethylene inhibitor depending on the orchard design and harvest date. Journal of Uman National University of Horticulture 92(1): 46-55. http://journal.udau.edu.ua/assets/files/92/Agro/5.pdf [in Ukrainian with English abstract]

Ekinci N., Şeker M., Aydin F., Gündoğdu M.A. 2016. Possible chemical mechanism and determination of inhibitory effects of 1-MCP on superficial scald of the 'Granny Smith' apple variety. Turkish Journal of Agriculture and Forestry 40: 38-44. DOI: 10.3906/tar-1411-91.

Etichetta/foglio illustrative. SmartFreshsm 14/09/2016: 1-4. http://www.fitosanitari.salute.gov.it/fitosanitariwsWeb_new/EtichettaServlet?id=26615. [in Italian]

Etykieta SmartFresh 03 VP. Ochrona Roslin. 2016: 1-4. https://www.ior.poznan.pl/baza/srodki_ochrony_roslin1223,smartfresh-03-vp.html. [in Polish]

Jeziorek K., Woźniak M., Tomala K. 2010. Response of 'Golden Delicious' apples to postharvest application of 1-methylcyclopropene (1-MCP) in conditions of normal and controlled atmosphere. Journal of Fruit and Ornamental Plant Research 18 (2): 223-237.

Magazin N., Keserović Z., Milić B., Miodragović M., Tarlanović J. 2017. The influence of 1-methylcyclopropene on fruit quality of "Granny Smith" apple cultivar depending on applied concentration and storage conditions. VI savetovanja "Inovacije u voćarstvu”, Belgrade, Serbia, pp. 99-106. [in Serbian with English abstract]

Melnyk O.V. 2010. Zbiral'na stiglist' âbluk: metod indukovanogo etilenu. Novini Sadivnictva 3: 36-37. [in Ukrainian]

Melnyk O., Drozd O. 2012a. Organoleptic evaluation of apples with post-harvest treatment with ethylene inhibitor. Journal of Uman National University of Horticulture 81(1): 233-238. http://journal.udau.edu.ua/assets/files/others/Zbirnik-UNUS81.Ch.1.pdf [in Ukrainian with English abstract]

Melnyk O., Drozd O. 2012b. Changing the physical parameters of apples from postharvest treatment the ethylene inhibitor. Ukrainian Black Sea Region Agrarian Science 4(68): 187-194. https://visnyk.mnau.edu.ua/statti/ar-

chive/n68v4r2012t1.pdf [in Ukrainian with English abstract]

Melnyk O., Drozd O., Melnyk I. 2017. Storage ability of Renette Simirenko apples treated with ethylene inhibitor after picking, depending on harvest date and type of orchard. Scientific Reports of NULES of Ukraine 1(65): 11 p. http://journals.nubip.edu.ua/index.php/Dopovidi/article/view/8112 [in Ukrainian with English abstract]

Moggia C., Hernández O., Pereira M., Lobos G.A., Yuri J.A. 2009. Effect of the cooling system and 1-MCP on the incidence of superficial scald in 'Granny Smith' apples. Chilean Journal of Agricultural Research 69(3): 383-390. DOI: 10.4067/s071858392009000300011.

Sisler E.C., Blankenship S.M. 1996. Methods of counteracting an ethylene response in plants. U.S. Patent $5,518,988$.

SmartFreshTM VP. 2016. https://middeldatabasenpdf.dlbr.dk/etikette/SmartFresh_VP_8331_Godkendt_Etikette_20160707.pdf. [in Germany]

Tomala K., Grzymała U., Jeziorek K., Woźniak M., Tomala W., Wojtalewicz M. et al. 2010. Sposoby poprawy jakości przechowalniczej jabłek. VI Międzynarodowe Targi Agrotechniki Sadowniczej “Czynniki wpływające na plonowanie i jakość owoców roślin sadowniczych”, Warszawa, pp. 107-123. [in Polish]

U. S. EPA, Pesticides, Label, SmartFresh technology 7/29/2010: 23. https://www3.epa.gov/pesticides/chem_search/ppls/071297-0000220100729.pdf. [in English]

Vidrih R., Hribar J., Zlatić E. 2011. The aroma profile of apples as influenced by 1-MCP. Journal of Fruit and Ornamental Plant Research 19(1): 101-111.

Watkins C.B., Nock J.F., Whitaker B.D. 2000. Responses of early, mid and late season apple cultivars to postharvest application of 1-methylcyclopropene (1MCP) under air and controlled atmosphere storage conditions. Postharvest Biology and Technology 19(1): 17-32. DOI: 10.1016/s09255214(00)00070-3. 